\title{
X. Red List of Amphibians and Reptiles of the Wadden Sea Area*
}

\author{
CONTRIBUTORS: \\ Denmark: K. Fog * \\ Germany: R. Podloucky, U. Dierking \\ The Netherlands: A. H. P. Stumpel
}

\section{INTRODUCTION}

The Wadden Sea area is a marginal habitat for most species of amphibians and reptiles. No amphibians and reptiles live in the areas flooded by the tides, and so only the islands are under consideration. Here, the shortage of fresh water is an important limiting factor; most amphibians need fresh water for breeding, although the Bufo species are able to breed in brackish water. Still, outside the breeding season adult amphibians need access to fresh water, e.g. rain or dew, in order not to die of desiccation. The same is true of reptiles. Therefore, it is difficult for these animals to survive in dunes and other habitats with a soil of coarse sand, where there is no access to water during droughts. In marshes which are intermittently flooded by sea water, the salinity of the water presents a problem of osmosis.

Only one species is well adapted to the above conditions, viz. the Natterjack Toad, Bufo calamita. In some places, e.g. Sylt and Mandø, it breeds seaward of the dikes. For all other species, occurrence in the Wadden Sea area is only fragmentary.

The poverty of species on the Wadden Sea islands has led to several intentional introductions, especially to the island of Juist, where $O$. Leege at the beginning of the century introduced no less than 16 species of amphibians and reptiles, of which only 2-3 species have survived. Thus, the absence of most species is due to lack of suitable habitats, while a few species may be lacking only because they have been unable to colonize the island in a natural way. Introductions to other islands are also known to have occurred, but are often less well documented. Therefore, in some cases it is unknown whether a population is natural in origin or is based on introduction.

\footnotetext{
- This list forms part of the Report on the RED LISTS OF BIOTOPES, FLORA AND FAUNA OF THE TRILATERAL WADDEN SEA AREA. For basic information concerning, for example, function of these lists, species taken into account, structure of the lists and abbreviations used, see also the general introduction to the Red Lists.

- Author of the introductory text.
} 


\section{Delimitation of the Area}

Apart from the occurrence of Bufo calamita, the amphibians and reptiles in general have more and stronger populations on the mainland than on the islands. In some cases, there are important and valuable populations in the low marshes outside the survey area behind the dikes, or elsewhere inland. Therefore, conditions behind the dikes, from where new individuals may migrate into areas in front of the dikes, should be taken into account.

\section{Information used and selection of species}

Lemmel \& Smit (1983) made a complete survey of what is known on amphibians and reptiles of the Wadden Sea islands, based on a thorough study of the literature, and on personal communications with the locals.

In addition to this information, more recent information is available from mapping projects in The Netherlands (Bergmans \& Zuiderwijk, 1986), Niedersachsen (Podloucky \& Fischer, 1991), Schleswig-Holstein (Dierking-Westphal, 1981) and Denmark (Fog, 1993). The data material which is the basis of these distribution maps is of very heterogeneous quality; systematic searches covering entire areas have not been performed. Therefore, the exact status of the species is generally not very precisely known, and the designation of threat categories should, therefore, in most cases be considered as qualified guesses. Only more systematic investigations in the field can remedy this state of affairs.

\section{Number of species}

Based on Lemmel \& Smit (1983), with additional data from more recent reports, the number of species of amphibians (A) and reptiles (R) can be stated as follows; i indicates number of introduced populations:

$\begin{array}{llll}\text { Texel: } & 5 \mathrm{~A} & \text { Neuwerk: } & 1 \mathrm{Ai} \\ \text { Wieringen: } & 4 \mathrm{~A} & \text { Helgoland: } & 2 \mathrm{Ai} \\ \text { Vlieland: } & 4 \mathrm{~A}, 1 \mathrm{R} & \text { Pellworm: } & 4 \mathrm{~A} \\ \text { Terschelling: } & 5 \mathrm{~A}, 2 \mathrm{R} & \text { Nordstrand: } & 3 \mathrm{~A}(1 \mathrm{i}) \\ \text { Ameland: } & 5 \mathrm{~A}, 1 \mathrm{R} & \text { Langeness: } & 1 \mathrm{~A} \text { ? } \\ \text { Schiermonnikoog: } & 4 \mathrm{~A}, 2 \mathrm{R} & \text { Amrum: } & 5 \mathrm{~A}, 1 \mathrm{R} \\ \text { Rottumeroog: } & 1 \mathrm{~A} & \text { Föhr: } & 6 \mathrm{~A}, 1 \mathrm{R} \\ \text { Borkum: } & 2 \mathrm{~A}, 1 \mathrm{Ri} . & \text { Sylt: } & 4 \mathrm{~A}, 2 \mathrm{R} \\ \text { Juist: } & 3 \mathrm{~A}(2 \mathrm{i}), 2 \mathrm{Ri} & \text { Rømø: } & 5 \mathrm{~A}, 2 \mathrm{R} \\ \text { Norderney: } & 2 \mathrm{~A}, 1 \mathrm{R} & \text { Mandø: } & 1 \mathrm{~A} \\ \text { Baltrum: } & 2 \mathrm{~A}(1 \mathrm{i}), 1 \mathrm{R} & \text { Fanø: } & 7 \mathrm{~A}, 5 \mathrm{R} \\ \text { Langeoog: } & 4 \mathrm{~A}, 1 \mathrm{R} & \text { Langli: } & 1 \mathrm{R} \\ \text { Spiekeroog: } & 3 \mathrm{~A}(2 \mathrm{i}), 2 \mathrm{R}(1 \mathrm{i}) & \text { Skallingen: } & 4 \mathrm{~A}, 3 \mathrm{R} \\ \text { Wangerooge: } & 2 \mathrm{~A}(1 \mathrm{i}), 1 \mathrm{Ri} & & \end{array}$

In addition, Lemmel \& Smit (1983) mention 25 islands and sands with no species of amphibians and reptiles. From the list it is apparent that the largest number of species 
occurs on the peripheral islands, whereas the German islands in the centre of the Wadden Sea are generally poor in species. The number of species on Fanø is much higher than on any other island.

The most widespread species is Bufo calamita, which is reported as natural on 22-23 islands, and as probably introduced on 2 islands.

\section{Decline}

If the results of the recent mapping projects are compared with the situation as it was reported by Lemmel \& Smit (1983), then it appears that a number of occurrences have not been confirmed in the most recent investigations. This is the case for Bufo bufo on 4 islands, Bufo calamita on 2 islands, the Rana esculenta complex on 2 islands, Rana temporaria on 3 islands, Lacerta agilis on 1 island, Lacerta vivipara on 6 islands, Natrix natrix on 1 island, and Vipera berus on 1 island.

It is not known if these species are extinct on the islands in question, or if they have just not been searched for with sufficient effort. It does suggest, however, that the situation for many populations is not secure, and that more extinctions may be expected in the future.

The rarest and/or most threatened species are:

Pelobates fuscus: Known only from one pond on Fanø. Actual situation unknown.

Anguis fragilis: Known only from Fanø. Introduced on 2 other islands, where it again died out.

Natrix natrix: Introduced and again extinct on 3 islands. Probably natural on Fanø, where it has not been recorded in recent times, however.

Vipera berus: Natural on Langli and Skallingen. Probably natural on Fanø, but not recorded there in recent times and probably extinct. Introduced and again extinct on 2-3 other islands.

\section{Populations inland on the mainland}

Some of the marsh areas behind the dikes are important amphibian habitats. Thus the "kogs" just north of the Danish-German border used to house huge populations of i.a. green frogs, populations which must be important as food resource for birds etc.

Whereas the marshes north of the Elbe river are inhabited by the edible frog, Rana esculenta, the marshes south of river Elbe are inhabited mainly or exclusively by the marsh frog, Rana ridibunda. This is especially true in Ostfriesland (Rahmel, 1988). The frogs occur in ditches near canals and open water bodies. These pure populations, without admixture of Rana lessonae or $R$. esculenta, are unique on a European scale, partly because pure $R$. ridibunda populations are very rare elsewhere, and partly because the species does not occur in this biotope elsewhere.

Thus, in a balanced effort to secure the amphibians in the Wadden Sea area, it is important to include the inland marshes.

The densest population of Pelobates fuscus in Denmark and in the Wadden Sea region are probably at Hjerpsted, very close to the sea border of the Wadden Sea. 


\section{Threat Factors and Conservation}

Amphibians depend on intact fresh-water breeding sites. They may also in some places depend on reed cutting, and be in danger where wetland becomes overgrown with dense Phragmites stands. Some species are threatened by eutrophication and destruction of ponds in cultivated areas. Lowering of the ground water level in dune areas, in order to increase supplies of municipal drinking water, will also be a threat.

The most important measure to safeguard the amphibians will be to protect marshes behind the dikes from further drainage and cultivation.

The reptiles occur in dune and heath biotopes. They depend on the possibility to migrate between biotopes with different microclimates (Elbing, 1992), and thus require intact connections between adjoining biotopes. They could be adversely affected by recreational activities, and possibly by the introduction of cats.

For amphibians and especially reptiles, traffic kills can be an important mortality factor.

\section{Summary}

In the Wadden Sea, in total, 8 species of amphibians and 4 species of reptiles are threatened in at least one subregion. Of these, 7 species of amphibians and all 4 species of reptiles are threatened in the entire area and are therefore placed on the trilateral Red List. 1 species of the listed reptiles is (probably) extinct in the entire Wadden Sea area. The status of 1 species of amphibians is endangered, the status of (probably) 4 species of amphibians and 3 species of reptiles are vulnerable and of 2 species of amphibians susceptible.

\section{REFERENCES}

Bergmans, W. \& A. Zuiderwijk, 1986. Atlas van de Nederlandse Amfibieen en Reptielen en hun Bedreiging. K. Ned. Natuurhist. Ver, Hoogwoud, 177 pp.

Dierking-Westphal, U., 1981. Zur Situation der Amphibien und Reptilien in Schleswig-Holstein. SchrReihe Landesamt für Naturschutz und Landschaftspflege Schleswig-Holstein 3, 1-109.

Elbing, K., 1992. Freilanduntersuchungen zur Populationsökologie und Fortpflanzungsbiologie der Zauneidechse (Lacerta agilis) auf der Insel Wangerooge. Dipl.-Arb., Univ. Bremen, 117 pp.

Fog, K., 1993. Opløg til forvaltningsplan for Danmarks padder og krybdyr. Miljøministeriet, Skovog Naturstyrelsen, København, $170 \mathrm{pp}$.

Lemmel, G. \& C. J. Smit, 1983. Distribution, ecology and zoogeography of amphibians and reptiles in the Wadden Sea area. In: Ecology of the Wadden Sea. Ed. by W. J. Wolff. Balkema, Rotterdam, $3,10 / 159-10 / 169$.

Podloucky, R. \& C. Fischer, 1991. Zur Verbreitung der Amphibien und Reptilien in Niedersachsen. Zwischenauswertung mit Nachweiskarten von 1981-1989. Niedersächsisches Landesverwaltungsamt, Fachbehörde für Naturschutz, Hannover, $38 \mathrm{pp}$.

Rahmel, U., 1988. Neue Daten zur Verbreitung des Seefrosches (Rana ridibunda) in Niedersachsen. - Jb. Feldherpetologie. Beih. 1, 47-66.

Rahmel, U. \& R. Eikhorst, 1988. Untersuchungen an den Laichplätzen von Moorfrosch (Rana arvalis) und Grasfrosch (Rana temporaria) auf den nordfriesischen Geestinseln Amrum, Föhr und Sylt. - Jb. Feldherpetologie 2, 47-66. 


\section{RED LIST OF AMPHIBIANS AND REPTILES OF THE WADDEN SEA AREA *}

EX - Extinct:

REPTILES:

(?) Natrix natrix

EN - Endangered:

AMPHIBIANS:

Pelobates fuscus

VU - Vulnerable:

AMPHIBIANS:

Bufo calamita

(?) Rana arvalis

Rana temporaria

(?) Triturus vulgaris
REPTILES:

Lacerta agilis

Lacerta vivipara

Vipera berus

SU - Susceptible:

AMPHIBIANS:

Rana esculenta

Rana ridibunda

- Question-marks indicate that in one of the subregions the status of threat is uncertain.

LIST OF THREATENED AMPHIBIANS AND REPTILES

OF THE WADDEN SEA AREA

\begin{tabular}{|c|c|c|c|c|c|c|c|}
\hline & & \multirow[t]{2}{*}{$\begin{array}{c}\text { Red List } \\
\text { (trilateral) }\end{array}$} & \multirow{2}{*}{ Threats } & \multicolumn{4}{|c|}{$\begin{array}{c}\text { Status of threat in the subregions of } \\
\text { the Wadden Sea Area }\end{array}$} \\
\hline & & & & NL & Nds & $\mathrm{SH}$ & DK \\
\hline \multicolumn{8}{|c|}{ AMPHIBIANS } \\
\hline $\begin{array}{l}\text { Bufo bufo } \\
\text { (Linnaeus 1758) }\end{array}$ & $\begin{array}{l}\text { Gewone Pad } \\
\text { Erdkröte } \\
\text { Skruptudse }\end{array}$ & * & & $\star$ & - & - & su \\
\hline $\begin{array}{l}\text { Bufo calamita } \\
\text { (Laurenti 1768) }\end{array}$ & $\begin{array}{l}\text { Rugstreeppad } \\
\text { Kreuzkrote } \\
\text { Strandtudse }\end{array}$ & vu & $\begin{array}{l}\text { HAB, DIS? } \\
\text { WAT }\end{array}$ & $*$ & VU & Vu & su \\
\hline $\begin{array}{l}\text { Rana arvalis } \\
\text { Nilsson } 1842\end{array}$ & $\begin{array}{l}\text { Heikikker } \\
\text { Moorfrosch } \\
\text { Spidssnudet frø }\end{array}$ & Vu? & HAB, EUT & VU & $?$ & VU & SU \\
\hline $\begin{array}{l}\text { Pelobates fuscus } \\
\text { (Laurenti 1768) }\end{array}$ & $\begin{array}{l}\text { Knoflookpad } \\
\text { Knoblauchkröte } \\
\text { Løgfrø }\end{array}$ & EN & FOR, WAT & - & - & - & EN \\
\hline $\begin{array}{l}\text { Rana esculenta } \\
\text { Linnaeus } 1758\end{array}$ & $\begin{array}{l}\text { Middel. Groene Kikker } \\
\text { Teichfrosch } \\
\text { Grøn frø }\end{array}$ & Su & & - & SU & - & SU \\
\hline $\begin{array}{l}\text { Rana ridibunda } \\
\text { Pallas } 1771\end{array}$ & $\begin{array}{l}\text { Meerkikker } \\
\text { Seefrosch } \\
\text { Latterfrø }\end{array}$ & su & & - & SU & - & - \\
\hline
\end{tabular}




\begin{tabular}{|c|c|c|c|c|c|c|c|}
\hline & & \multirow[t]{2}{*}{$\begin{array}{l}\text { Red List } \\
\text { (trilateral) }\end{array}$} & \multirow{2}{*}{ Threats } & \multicolumn{4}{|c|}{$\begin{array}{c}\text { Status of threat in the subregions of } \\
\text { the Wadden Sea Area }\end{array}$} \\
\hline & & & & NL & Nds & $\mathrm{SH}$ & DK \\
\hline $\begin{array}{l}\text { Rana temporaria } \\
\text { (Linnaeus 1758) }\end{array}$ & $\begin{array}{l}\text { Bruine Kikker } \\
\text { Grasfrosch } \\
\text { Butsnudet frø }\end{array}$ & Vu & HAB, WAT & * & Vu & VU & su \\
\hline $\begin{array}{l}\text { Triturus vulgaris } \\
\text { (Linnaeus 1758) }\end{array}$ & $\begin{array}{l}\text { Kleine Watersalamander } \\
\text { Teichmolch } \\
\text { Lille vandsalamander }\end{array}$ & VU? & & $*$ & $?$ & EN & $?$ \\
\hline \multicolumn{8}{|c|}{ REPTILES } \\
\hline $\begin{array}{l}\text { Lacerta agilis } \\
\text { Linnaeus } 1758\end{array}$ & $\begin{array}{l}\text { Zandhagedis } \\
\text { Zauneidechse } \\
\text { Markfirben }\end{array}$ & VU & HAB, DIS? & EN & Vu & VU & * \\
\hline $\begin{array}{l}\text { Lacerta vivipara } \\
\text { Jacquin } 1787\end{array}$ & $\begin{array}{l}\text { Levendbarende Hagedis } \\
\text { Waldeidechse } \\
\text { Almindeligt firben }\end{array}$ & Vu & $\mathrm{HAB}, \mathrm{DIS} ?$ & EN & VU & Vu & $*$ \\
\hline $\begin{array}{l}\text { Natrix natrix } \\
\text { (Linnaeus } 1758)\end{array}$ & $\begin{array}{l}\text { Ringsiang } \\
\text { Ringelnatter } \\
\text { Snog } \\
\end{array}$ & EX? & WAT & - & - & - & EX? \\
\hline $\begin{array}{l}\text { Vipera berus } \\
\text { (Linnaeus 1758) }\end{array}$ & $\begin{array}{l}\text { Adder } \\
\text { Kreuzotter } \\
\text { Hugorm }\end{array}$ & Vu & HAB, DIS & - & - & - & VU \\
\hline
\end{tabular}

\section{Status of threat:}

$\mathbf{E X}=$ Extinct $\mathbf{C R}=$ Critical $; \mathbf{E N}=$ Endangered $; \mathbf{V U}=$ Vulnerable; $\mathbf{S U}=$ Susceptible; ${ }^{*}=$ not endan gered $_{i} ?=$ status of endangerment is not exactly known; $-=$ species does not occur; $-($ ? $)=$ species probably does not occur $\left(^{*}\right)=$ it is unknown if or if not this species occurs.

Threats:

$\mathrm{AFF}$ = afforestation; $\mathrm{AGR}=$ agriculture; $\mathrm{CLI}=$ climatic change DIS = disturbance; $\mathrm{EUT}=$ eutrophication; $E X L=$ exploitation of living resources; $E X M=$ mineral exploitation; $F O R=$ forestry; $H A B=$ loss of habitat $; \mathrm{PAR}=$ parasites $; \mathrm{POL}=$ pollution $; \mathrm{WAT}=$ water regulation .

For more detailed descriptions see the general introduction to the Red Lists. 